\title{
The Effects of Grazing Intensity on Annual Vegetation
}

\author{
MICHAEL D. PITT AND HAROLD F. HEADY
}

\begin{abstract}
Pastures grazed by sheep at moderate and 11/2-, 2-, and 21/2times the moderate stocking rate from $1969-1973$ were analyzed for relative changes in cover, herbage productivity, and botanical composition. All four pastures were less productive in 1973 than in 1969, but exhibited similar trends in cover and botanical composition regardless of grazing intensity. Only grazing at $2 \frac{1}{2}$ times the moderate stocking rate produced a residual decline in productivity following 1 year of rest from the grazing treatment. However, this decline in productivity was managerially negligible compared to other stocking rates, and would probably disappear within 2-3 years in response to the overriding influence of annual weather, especially precipitation, patterns.
\end{abstract}

Hormay (1944) suggested that moderate stocking rates provided the best grazing technique in the annual type. Old vegetation left on the ground at the end of each grazing season would enhance soil fertility, provide progressively improved range condition, and ultimately promote high livestock weight gains. Grazing either greater or less than this moderate level would produce changes in both total herbage productivity and relative botanical composition. Heady (1958) postulated that grazing occurred first on taller plant species, thereby increasing the relative proportion of shorter plant species. Alternatively, complete elimination of grazing animals encouraged taller annual plants relative to short plant species. Talbot et al. (1939), Talbot and Biswell (1942), and Jones and Evans (1960) all found that exclusion of grazing animals quickly led to grass dominance, particularly taller species, such as ripgut (Bromus rigidus). Biswell (1956) held the opinion that this increase in ripgut occurred at the expense of true clovers (Trifolium spp.) and bur-clover (Medicago hispida), with plant succession proceeding from forbs to soft chess (Bromus mollis), to wild oats (Avena spp.) to ripgut.

Biswell (1956) hypothesized that the impact of grazing on botanical composition in the annual type operated primarily by altering the accumulation of mulch. Heady (1958, 1961) supported Biswell's hypothesis by demonstrating that mulch exceeding 700 pounds per acre in Northern California encouraged taller grasses such as soft chess and ripgut. With no mulch accumulation small, unpalatable forbs such as goldfields (Baeria chrysostoma), smooth cat's ear (Hypochoeris glabra), and owl's clover (Orthocarpus erianthus) proliferated. With small amounts of mulch, diminutive, low-forage-valuc grasses such as little quaking grass (Briza minor) and silver hairgrass (Aira caryophyllea) abounded. Annual fescues (Festuca spp.)

Authors are assistant professor of range ecology. University of British Columbia Department of Plant Science, Vancouver, Canada V6T IW5; and professor of range management, University of California, Berkeley 94720 .

Manuscript received February 20, 1979. and nitgrass (Gastridium ventricosum) peaked in percent botanical composition with intermediate amounts of mulch, while filaree (Erodium spp.) was not significantly influenced by varying amounts of mulch.

The amount of mulch present during germination exerts a major influence on total herbage productivity as well as botanicanl composition. Hooper and Heady (1970), at the Hopland Field Station in Northern California, discovered that removing all mulch prior to germination drastically reduced subsequent forage production compared to sites where mulch was not removed. Importantly, a single manipulation stimulated this response, and a moderate amount of mulch produced maximum herbage productivity.

Although mulch influences botanical composition and herbage productivity of the annual type within a particular growing season, these differences are temporary and tend to persist only so long as the grazing and/or clipping treatments are maintained. At the San Joaquin Experimental Range, both Talbot and Biswell (1942) and Bentley and Talbot (1951) noted no pronounced, long-term effects in total yield as a result of grazing at both light and heavy stocking rates. However, these results cannot be readily applied to other areas in the annual type where forage production potentials are confounded by local seasonal variability and/or microsite differences (Biswell 1956; Heady 1961; Smith 1970). Rossiter (1966) concluded that such microsite variabilitics accounted for the lack of quantitative data describing the long-term impact of stocking rates on productivity and botanical composition throughout much of the annual type. This paper provides data describing the residual impact of grazing on annual vegetation occurring in the coastal mountain ranges of Northern California.

\section{Location and Methods of Study}

The study was conducted at the Hopland Field Station located in Mendocino County in the central portion of the coast mountain ranges. The climate of the area is subhumid to humid mesothermal. The winters are mild with occasional frost in valley bottoms, and infrequent, light snow at higher elevations. The average annual rainfall is $89 \mathrm{~cm}$ with virtually no rain falling between June and September. Fog occurs frequently in valley bottoms during late fall, winter, and early spring, and occasionally during the summer. Average summer and fall temperatures range from $20-25^{\circ} \mathrm{C}$ (Pitt 1975).

The pastures used in this study were initially fenced in 1953 to investigate the impact of continuous versus rotational grazing on both animal performance and vegetational response (Pitt 1975). Beginning in 1961, these pastures enclosing approximately 11 ha each were calibrated to equalize grazing intensity. Equal grazing intensity among pastures S1, S2, S3, and S7 occurred when: (1) lamb weights at 120 
days were similar in all pastures, and (2) equal ewe weight loss at the end of the dry period occurred in all pastures.

The following grazing treatments existed in the summer of 1962: S1, S3, and S7 contained 13 sheep, while S2 supported 20 sheep. These pastures operated on a yearlong basis throughout the calibration period during which time numbers of animals were adjusted in each pasture to obtain as near equal gains and losses as possible per individual among all pastures. This grazing intensity was on the heavy side of stocking so that animals were under stress and their weights reflected pasture effects rather than effects due to inherent properties of individual animals. The number of sheep in each pasture at the end of the calibration period in the summer of 1964 constituted a standard stocking intensity for all future experiments.

The study investigating effects of different grazing intensities on annual vegetation began in the 1968-1969 grazing season. The calibrated stocking rate continued in pasture $S 3$, while $11 / 2-, 2-$, and $21 / 2$-times the previous calibrated stocking rates were introduced into pastures S1, S7, and S2, respectively. All pastures were grazed on a continuous yearlong basis with the same animals, insofar as possible.

Vegetation was sampled twice each year: once at the beginning of the growing season in the fall of each year, and again at the end of the growing season in June. Each pasture contained 24 sampling locations consisting of a $1-\mathrm{m}$ diameter wire mesh exclosure and an outside stake. Each exclosure occurred in a homogeneous sampling unit approximately $8 \mathrm{~m}$ in diameter. Exclosure and associated outside stakes were moved prior to each fall sampling date to a different but vegetationally similar spot within this sampling unit. Changes noted in botanical composition or herbage productivity throughout the course of the study were therefore not the result of repeated sampling of the same location.

Herbage productivity of each pasture was estimated by clipping a square plot $0.099 \mathrm{~m}^{2}$ in size $\left(1 \mathrm{ft}^{2}\right)$ to ground level at each sampling location, while botanical composition, cover, and height of annual vegetation were estimated with 30 points taken with a 10-point frame. All of these parameters, both inside and outside the exclosures, were estimated at the June sampling date, while only outside herbage productivity was measured at the fall sampling date.

\section{Vegetational Responses}

Tables 1, 2, 3, and 4 summarize data collected in pastures S3, S1, S7, and S2, respectively. Only those values for ungrazed June vegetation are listed. Vegetational parameters measured in June, the end of the growing season, characterize the yearly response of annual vegetation to each associated animal stocking rate. Measurements in ungrazed vegetation characterize the carryover effect of stocking rate from one year to the next. Since the cages are moved each year, ungrazed vegetation reflects the residual impact of stocking rate 1 year following removal of grazing. Alternatively, measurements in grazed vegetation primarily reflect vegetational variability within a single growing or grazıng season and may not indicate the impact of stocking rate over time. Ungrazed June vegetation in 1969 represents baseline values and not the result of any stocking rate treatments. Ungrazed June vegetation in 1973 represents values resulting from 4 years of stocking rate treatment followed by 1 year of rest.

Table 5 summarizes results from a two-way analysis of variance analyzing the impacts of stocking rate and yearly variability on herbage productivity, cover, and botanical composition. Ungrazed June vegetation in 1969 was not subjected to any grazing treatment. Therefore, only 4 years of data, ungrazed June vegetation for the years 1970 through 1973 inclusive, were used in this analysis. Many researchers have described the dramatic impact of yearly weather patterns on annual vegetation (Talbot et al. 1939; Bentley and Talbot 1951; Heady 1956; Heady 1958; Naveh 1967; McNaughton 1968; Hooper and Heady 1970; Murphy 1970; Duncan and Woodmansee 1975; Pitt 1975). These studies all indicate that observed trends in standing crop, cover, and botanical composition in annual vegetation may be the result of annual weather patterns as well as stocking rate treatments. Therefore, the impacts of stocking rate, yearly variability, and particularly the

Table 1. Average percent botanical composition, cover (\%), and standing crop $\left(\mathrm{g} / \mathrm{m}^{2}\right)$ on pasture $\mathrm{S3}$, 1969-1973. Grazed at the moderate stocking rate.

\begin{tabular}{|c|c|c|c|c|c|}
\hline Plant species & 1969 & 1970 & 1971 & 1972 & 1973 \\
\hline Aira caryophyllea & 10.5 & 10.9 & 13.6 & 28.4 & 29.5 \\
\hline Avena barbata & 3.1 & 3.8 & 5.0 & 5.6 & 0.3 \\
\hline Bromus mollis & 18.3 & 19.6 & 14.9 & 19.4 & 30.9 \\
\hline Bromus rigidus & 1.3 & 3.1 & 0.0 & 2.1 & 3.7 \\
\hline Bromus rubens & 1.8 & 1.5 & 0.0 & 1.3 & 0.5 \\
\hline Festuca spp. & 3.5 & 6.9 & 2.5 & 7.4 & 4.4 \\
\hline Gastridium ventricosum & 0.4 & 1.4 & 1.3 & 0.6 & 0.5 \\
\hline Hordeum spp. & 1.3 & 0.0 & 0.0 & 0.0 & 0.0 \\
\hline Other annual grasses & 0.4 & 2.8 & 2.6 & 1.4 & 1.7 \\
\hline Perennial grasses and grasslike plants & 2.2 & 0.0 & 4.3 & 1.7 & 0.0 \\
\hline Medicagohispida & 0.0 & 0.0 & 0.0 & 0.0 & 0.0 \\
\hline Trifolium spp. & 12.7 & 7.2 & 12.6 & 3.8 & 12.1 \\
\hline Vicia spp. & 0.0 & 0.0 & 0.0 & 0.0 & 0.0 \\
\hline Other legumes & 1.8 & 5.3 & 4.0 & 2.6 & 2.9 \\
\hline Baeria chrysostoma & 0.4 & 0.7 & 0.0 & 0.5 & 1.3 \\
\hline Carduus pycnocephalus & 0.0 & 0.0 & 0.0 & 0.0 & 0.5 \\
\hline Daucus pusillus & 5.7 & 1.5 & 3.6 & 4.1 & 2.2 \\
\hline Erodium spp. & 20.0 & 18.3 & 11.7 & 8.5 & 3.0 \\
\hline Geranium spp. & 0.9 & 0.6 & 0.5 & 0.3 & 0.0 \\
\hline Hypochoeris glabra & 2.6 & 4.0 & 2.8 & 3.0 & 2.0 \\
\hline Perennial forbs & 3.9 & 6.2 & 1.8 & 2.6 & 0.5 \\
\hline Other early annual forbs & 6.6 & 2.3 & 10.2 & 6.7 & 3.7 \\
\hline Other late annual forbs & 2.6 & 2.7 & 2.2 & 0.0 & 0.3 \\
\hline Cover & 31.8 & 36.2 & 40.1 & 66.9 & 75.3 \\
\hline Standing crop & 226.0 & 168.9 & 201.2 & 167.9 & 202.3 \\
\hline
\end{tabular}


Table 2. Average percent botanical composition, cover $(\%)$, and standing crop $\left(\mathrm{g} / \mathrm{m}^{2}\right)$ on pasture $\mathrm{S} 1,1969-1973$. Grazed at $1 \frac{1}{2}$ times the moderate stocking rate.

\begin{tabular}{|c|c|c|c|c|c|}
\hline Plant species & 1969 & 1970 & 1971 & 1972 & 1973 \\
\hline Aira caryophyllea & 14.5 & 0.6 & 13.8 & 41.1 & 31.4 \\
\hline Avena barbata & 0.8 & 0.0 & 0.4 & 1.3 & 0.0 \\
\hline Bromus mollis & 20.0 & 33.2 & 12.2 & 19.2 & 22.4 \\
\hline Bromus rigidus & 0.0 & 1.4 & 0.0 & 0.0 & 0.2 \\
\hline Bromus rubens & 3.4 & 10.3 & 8.4 & 7.4 & 2.7 \\
\hline Festuca spp. & 1.3 & 2.2 & 3.0 & 6.2 & 2.3 \\
\hline Gastridium ventricosum & 0.4 & 1.3 & 2.4 & 1.6 & 0.7 \\
\hline Hordeum spp. & 0.0 & 0.0 & 0.0 & 0.0 & 0.0 \\
\hline Other annual grasses & 0.4 & 0.0 & 0.0 & 0.3 & 0.0 \\
\hline Perennial grasses and grasslike plants & 0.0 & 0.0 & 0.0 & 0.0 & 0.0 \\
\hline Medicago hispida & 1.7 & 1.4 & 1.0 & 0.0 & 1.9 \\
\hline Trifolium spp. & 23.8 & 17.2 & 17.2 & 5.3 & 13.9 \\
\hline Vicia spp. & 0.0 & 0.0 & 0.0 & 0.0 & 0.0 \\
\hline Other legumes & 4.3 & 2.8 & 7.7 & 2.7 & 4.7 \\
\hline Baeria chrysostoma & 0.0 & 0.0 & 0.0 & 0.0 & 0.0 \\
\hline Carduus pycnocephalus & 0.0 & 0.0 & 0.0 & 0.0 & 0.0 \\
\hline Daucus pusillus & 4.3 & 2.2 & 6.3 & 5.9 & 2.5 \\
\hline Erodium spp. & 16.6 & 16.1 & 8.8 & 1.6 & 5.6 \\
\hline Geranium spp. & 0.4 & 0.0 & 1.6 & 1.2 & 1.0 \\
\hline Hypochoeris glabra & 0.8 & 1.7 & 2.6 & 1.0 & 2.0 \\
\hline Perennial forbs & 0.0 & 0.0 & 0.0 & 0.0 & 0.0 \\
\hline Other early annual forbs & 5.1 & 3.9 & 13.5 & 5.3 & 8.5 \\
\hline Other late annual forbs & 0.4 & 0.0 & 0.0 & 0.0 & 0.0 \\
\hline Cover & 32.6 & 32.1 & 34.8 & 57.2 & 66.4 \\
\hline Standing crop & 119.4 & 108.7 & 122.7 & 83.9 & 92.5 \\
\hline
\end{tabular}

interaction of stocking rate and yearly variability must be evaluated carefully. Stocking rates were calibrated in terms of animal response. Tables 1 through 4 indicate that standing crop and botanical composition at the beginning of the study in 1969 varied tremendously among pastures. Therefore, a statistically significant result for the main effect of stocking rate may reflect inherent pasture differences rather than variable responses to stocking rate. Indeed, only statistically significant interactions between stocking rate and year suggest a long-term response of annual vegetation to stocking rates. This response has truly

Table 3. Average percent botanical composition, cover $(\%)$, and standing crop $\left(\mathrm{g} / \mathrm{m}^{2}\right)$ on pasture $\mathrm{S7}, 1969-1973$. Grazed at 2 times the moderate stocking rate.

\begin{tabular}{|c|c|c|c|c|c|}
\hline Plant species & 1969 & 1970 & 1971 & 1972 & 1973 \\
\hline Aira caryophyllea & 10.9 & 4.2 & 18.1 & 37.7 & 28.3 \\
\hline Avena barbata & 0.3 & 0.0 & 0.3 & 0.4 & 0.0 \\
\hline Bromus mollis & 11.3 & 18.7 & 3.9 & 11.0 & 12.7 \\
\hline Bromus rigidus & 0.7 & 1.2 & 0.0 & 0.0 & 0.0 \\
\hline Bromus rubens & 1.0 & 0.3 & 0.4 & 0.0 & 0.2 \\
\hline Festuca spp. & 9.6 & 10.9 & 11.3 & 10.2 & 13.1 \\
\hline Gastridium ventricosum & 2.0 & 0.8 & 4.4 & 6.6 & 1.0 \\
\hline Hordeum spp. & 0.7 & 0.3 & 0.0 & 0.0 & 0.0 \\
\hline Other annual grasses & 1.3 & 0.7 & 0.8 & 0.2 & 0.6 \\
\hline Perennial grasses and grasslike plants & 0.3 & 0.0 & 0.7 & 0.5 & 0.5 \\
\hline Medicago hispida & 2.6 & 1.3 & 4.8 & 0.2 & 1.3 \\
\hline Trifolium spp. & 8.9 & 5.8 & 6.7 & 2.6 & 12.8 \\
\hline Vicia spp. & 0.0 & 0.0 & 0.0 & 0.0 & 0.0 \\
\hline Other legumes & 0.3 & 0.7 & 0.5 & 1.5 & 0.4 \\
\hline Baeria chrysostoma & 3.3 & 1.8 & 0.8 & 4.3 & 4.2 \\
\hline Carduus pycnocephalus & 0.0 & 0.0 & 0.3 & 0.0 & 0.0 \\
\hline Daucus pusillus & 2.6 & 0.6 & 2.7 & 0.5 & 0.9 \\
\hline Erodium spp. & 31.1 & 37.5 & 11.9 & 12.1 & 11.5 \\
\hline Geranium spp. & 0.7 & 0.0 & 0.9 & 0.0 & 0.9 \\
\hline Hypochoeris glabra & 5.6 & 4.0 & 6.3 & 6.1 & 4.0 \\
\hline Perennial forbs & 0.7 & 0.0 & 0.0 & 0.2 & 0.2 \\
\hline Other early annual forbs & 4.6 & 11.1 & 15.1 & 5.6 & 7.2 \\
\hline Other late annual forbs & 1.3 & 0.0 & 0.5 & 0.2 & 0.0 \\
\hline Cover & 41.9 & 39.3 & 38.7 & 73.6 & 83.5 \\
\hline Standing crop & 361.6 & 260.4 & 274.4 & 182.9 & 198.0 \\
\hline
\end{tabular}




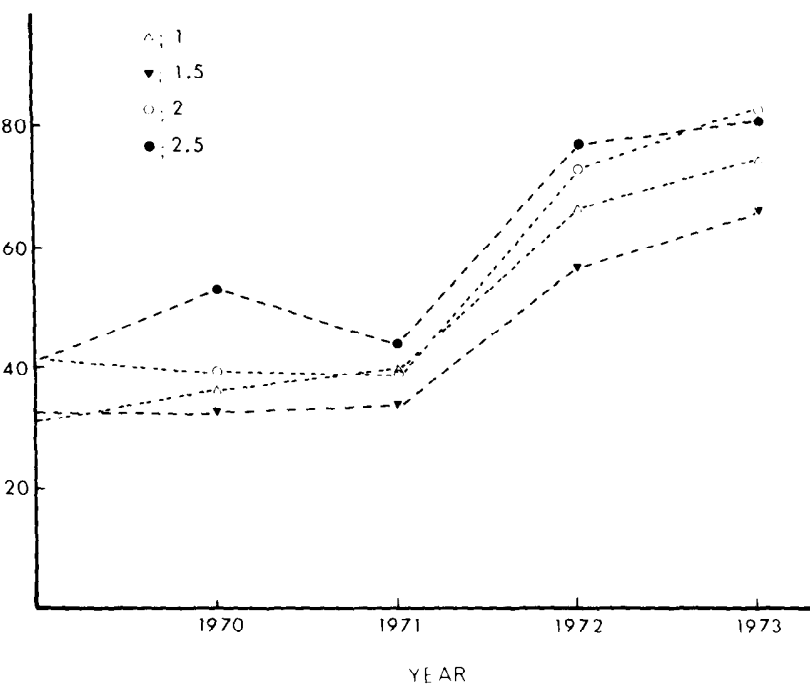

Fig. 2. Influence of moderate (1), 11/2-, 2-, and 21/2-times the moderate stocking rate on percent cover, 1969-1973.

as cover in $\mathrm{S} 2$ increased from 40.7 to $85.5 \%$ during the study period.

Any changes in standing crop and percent cover must be associated with corresponding changes in botanical composition. Both nitgrass $(<0.01)$ and bur-clover $(p<0.10$ in Table 5) produced significant interactions between grazing intensity and yearly variability. However, nitgrass comprised only a very small portion of the vegetative cover, averaging $0.5,0.7,1.0$, and $0.5 \%$ in June 1973, in pastures S3, S1, S7 and S2, respectively. The significant interaction for nitgrass resulted primarily trom the exceptionally high value of $6.6 \%$ botanical composition in pasture S7 in June of 1972. However, this unique value for nitgrass probably arose from some factor other than grazing intensity, as all pastures supported small proportions of nitgrass both at the beginning and the end of the study.

Bur-clover, like nitgrass, comprised only small proportions of the vegetative cover in all pastures throughout the study period (Tables 1-4). Therefore, statistically significant interactions for these two plant species between grazing and year of treatment cannot explain the relative changes in herbage productivity and cover observed in pasture $\mathbf{S} 2$. These changes can be explained only by associated changes for plant species such

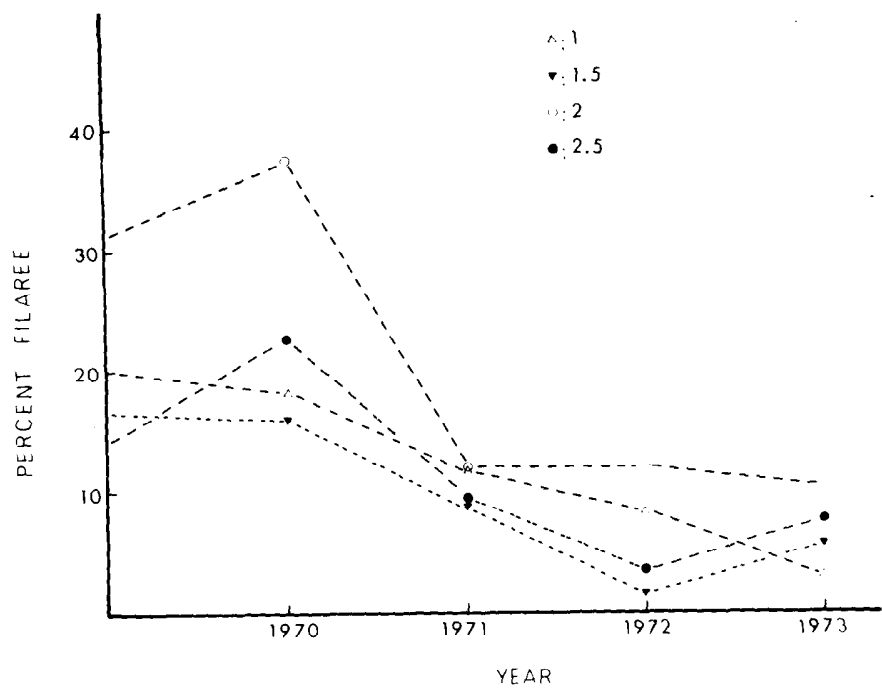

Fig. 3. Influence of moderate (l), /1/2-, 2-, and 21/2-times the moderate stocking rate on proportion if filaree (Erodium spp.), 1969-1973.

as filaree and soft chess, which composed significant portions of the total vegetative cover on the sheep/deer pastures.

Filaree, a successional plant species, commonly occupies disturbed or heavily grazed sites. Conversely, this plant species declines on undisturbed or lightly grazed areas where taller annual plant species are favored. These relationships are illustrated by Figure $3(p<0.05$ in Table 5$)$. Percent botanical composition for filaree declined in all four pastures from 1970-1972, indicating that filaree probably responded more to changing weather patterns than to different grazing intensities. From 1972 to 1973 , however, filaree increased in all pastures except S3, which was grazed at the lightest stocking rate. Apparently, weather patterns during the last year of study initiated an increase in percent composition for filaree except in areas (pasture S3) where moderate grazing and relatively undisturbed conditions discouraged the growth of filaree.

In contrast to filaree, soft chess typically increases in response to undisturbed conditions and subsequent accumulating mulch. From 1970-1972, percent botanical composition of soft chess followed identical directional trends in all four pastures (Fig. 4). Like filaree, however, soft chess displayed different trends among grazing treatments during the last year of study. Only the heaviest stocking rate (pasture S2) produced a

Table 5. Summary of the impact of grazing intensity on botanical composition and standing crop at the Hopland Field Station, $1970-1973$.

\begin{tabular}{|c|c|c|c|c|c|c|c|c|}
\hline & $\mathrm{AiCa}^{1}$ & $\mathrm{AvBa}$ & $\mathrm{BrMo}$ & $\mathrm{Br} \mathrm{Ri}$ & $\mathrm{Br} \mathrm{Ru}$ & Fes & $\mathrm{GaVe}$ & Hor \\
\hline Stocking Rate (S) & $* * * 2$ & $* * * *$ & $* * * *$ & $* * * *$ & $* * * *$ & $* * * *$ & $* * * *$ & \\
\hline Year $(Y)$ & $* * * *$ & & $* * * *$ & $*$ & & & $* * * *$ & \\
\hline$S \times Y$ & & & $*$ & & * & & $* * * *$ & \\
\hline Stocking Rate (S) & $\underset{* * * *}{\operatorname{Ann} \mathrm{G}}$ & $\begin{array}{l}\text { PerG } \\
*\end{array}$ & $\underset{* * * *}{\mathrm{Me} \mathrm{Hi}}$ & $\begin{array}{l}\text { Tri } \\
* * * *\end{array}$ & $\begin{array}{l}\text { Leg. } \\
* * * *\end{array}$ & $\begin{array}{l}\mathrm{BaCh} \\
* * * *\end{array}$ & $\mathrm{CaPy}$ & $\underset{* * * *}{\mathrm{DaPu}}$ \\
\hline $\begin{array}{l}\text { Year }(Y) \\
S \times Y\end{array}$ & & & $\begin{array}{l}* \\
* *\end{array}$ & $* * * *$ & $\begin{array}{l}* \\
*\end{array}$ & $* * *$ & & $* * *$ \\
\hline \multirow[t]{2}{*}{$\mathrm{S} \times \mathrm{Y}$} & & & ** & & $*$ & & & \\
\hline & $\begin{array}{l}\text { Ero. } \\
* * * *\end{array}$ & Ger & Hy Gl & P Fbs & $\underset{* * *}{\mathrm{EAFb}}$ & $\mathrm{LAFb}$ & Cover & S. Crop \\
\hline Stocking Rate (S) & $\begin{array}{l}* * * * \\
* * * *\end{array}$ & & $* * * *$ & $* * * *$ & $* * *$ & $* * * *$ & $* * * *$ & $* * * *$ \\
\hline $\begin{array}{l}\text { Year }(Y) \\
S \times Y\end{array}$ & $\begin{array}{l}* * * * \\
* * *\end{array}$ & $* *$ & & & $* * * *$ & $* *$ & $* * * *$ & $* * * *$ \\
\hline $\mathrm{S} \times \mathrm{Y}$ & $* * *$ & & & & & & $* * *$ & $* * *$ \\
\hline
\end{tabular}

\footnotetext{
'Symbols for plants and plant categories as given in Tables $1-4$

$\because * x_{*}=$ significant at $p<0.01$

s:s = significant at $p<0.05$.

$=$ significant at $p<0.10$

$=$ signiticant at $p<0.20$.
} 


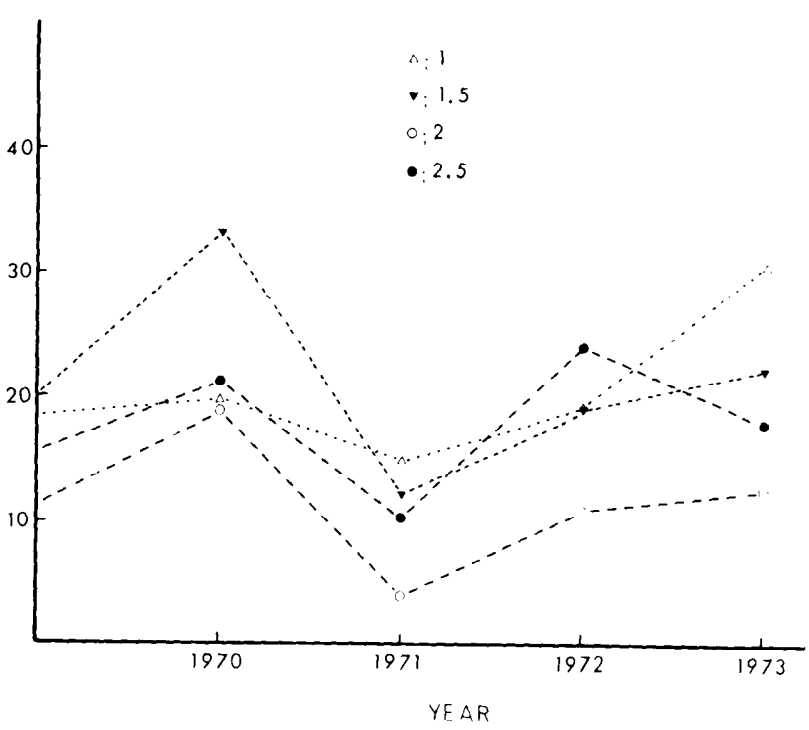

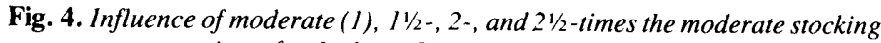
rate on proportion of soft chess (Bromus mollis), 1969-1973.

decline in botanical composition for soft chess, which increased in all other pastures. Moreover, the most dramatic increase for soft chess for the period 1972-1973 occurred in the moderately grazed pasture S3, which produced the only observed decline for filaree during this same year.

\section{Conclusions}

Soft chess and filaree occupy climax and intermediate stages of plant succession, respectively. From 1972-1973 these two plant species displayed opposite trends in botanical composition as a function of earlier grazing intensity. Soft chess increased in response to moderate grazing pressure (pasture S3) but decreased in response to heavy grazing pressure (pasture S2). Conversely, filaree declined under moderate stocking while increasing under heavy stocking rates. These results indicate that extremes of grazing intensity can produce residual impacts on botanical composition of soft chess and filaree for at least 1 year following removal of grazing animals. These residual impacts are consistent with the successional stages of soft chess and filaree and may result from the influence of different levels of mulch on germination and subsequent growth. However, mulch accumulation as a function of grazing intensity does not exert as much influence on botanical composition as do variable weather patterns. From 1970-1972, both filaree and soft chess responded similarly among all four pastures regardless of grazing treatment. Thus, grazing intensity only infrequently exerted a 1 -year residual impact on botanical composition. Even this residual impact, because of the more significant influence of annual weather patterns on botanical composition of annual vegetation, would rarely last 2 or 3 years.
These same conclusions also apply to cover and herbage productivity, which responded similarly among all four pastures throughout the study period. Although very heavy grazing apparently depressed forage production during the final year of study, absolute productivity differences between moderate and heavy grazing pressures remained managerially insignificant. Moreover, annual variability for both cover and productivity within each stocking rate was more pronounced than the relative differences between stocking rates. Therefore, the residual influences of grazing on cover and total forage production are negligible when compared to these same influences of annual weather patterns. Indeed, following only a single year of rest from grazing animals, both cover and forage production in all four pastures generally responded to annual growing conditions as if no previous grazing treatments existed. Finally, results from this study give further confirmation that the California annual grassland is tolerant to a wide range of stocking rates and degrees of herbage utilization.

\section{Literature Cited}

Bentley, J.R., and M.W. Talbot. 1951. Efficient use of annual plants on cattle ranges in the California foothills. U.S. Dep. Agr. Circ. 870.

Biswell, H.H. 1956. Ecology of California grasslands. J. Range Manage. 9:19-24.

Duncalı, D.A., and R.G. Woodmansee. 1975. Forecasting forage yield from precipitation in California's annual rangeland. J. Range Manage. 28:327329.

Heady, H.F. 1965. Evaluation and measurement of the California annual type. J. Range Manage. 9:25-27.

Heady, H.F. 1958. Vegetational changes in the California annual type. Ecology. 39:402-415.

Heady, H.F. 1961. Continuous vs. specialized grazing systems: A review and application to the California annual type. J. Range Manage. 14:182-193.

Hooper, J.F., and H.F. Heady. 1970. An economic analysis of optimum rates of grazing in the California annual-type grassland. J. Range Manage. 23:307311.

Hormay, A.L. 1944. Moderate grazing pays on California annual-type ranges. U.S. Dep. Agr. Leaflet 239.

Jones, M.B., and R.A. Evans. 1960. Botanical composition changes in annual grassland as affected by fertilization and grazing. Agron. J. 52:459-461.

McNaughton, S.J. 1968. Structure and function in California grasslands. Ecology. 49:962-972.

Murphy, A.H. 1970. Predicted forage yield based on fall precipitation in California annual grasslands. J. Range. Manage. 23:363-365.

Nevah, Z. 1967. Mediterranean ecosystems and vegetation types in California and Israel. Ecology. 48:445-459.

Pitt, M.D. 1975. The effects of site, season, weather patterns, grazing, and brush conversion on annual vegetation, Watershed II, Hopland Field Station. Univ. California PhD Diss. $281 \mathrm{p}$.

Rossiter, R.C. 1966. Ecology of the Mediterranean annual-type pasture Adv. in Agron. 18:1-56.

Smith, T.A. 1970. Effects of disturbance on seed germination in some annual plants. Ecology. 51:1106-1108.

Talbot, M.W., and H.H. Biswell. 1942. The forage crop and its management. Univ. California Agr. Exp. Sta. Bull. 663:13-49.

Talbot, M.W., H.H. Biswell, and A.L. Hormay. 1939. Fluctuations in the annual vegetation of California. Ecology. 20:394-402. 